\title{
Temporary use of space: Urban processes between flexibility, opportunity and precarity Ali Madanipour
}

Article in press (2017) in Urban Studies

\begin{abstract}
The temporary use of privately-owned, empty space has been advocated by some as economically-sensible and socially-progressive, making use of unproductive and empty spaces by providing access to space for those who are otherwise unable to do so. The paper critically examines this concept, arguing that the temporary use of space should be analysed as part of the urban development process with its temporal and spatial fluctuations and its multivalent outcomes. It investigates the production of empty space and the temporary use of space as a space of opportunity and a flexible method of production. By drawing on the case of Chesterfield House in London, in the context of the British response to the global financial crisis, the temporary use of space is shown to be a moment in a complex process, offering some opportunities, but also revealing the brevity of this moment and the precarity of its users. Beyond the realm of necessity, it may be transformed into a cultural choice, a lubricant of urban development, and a medium of social change, signifying a space of opportunity for some and vulnerability for others.
\end{abstract}

Keywords: temporary urbanism, spatial production, flexibility, opportunity, precarity

The temporary use of space has become a major urban trend, attracting increasing popular, policy, and academic attention (Cochrane,2010; Bishop and Williams,2012; Colomb,2012). This attention has tended to be affirmative, seeing it as an opportunity for regeneration and renewal (Berwyn,2013; Steele,3013). Some analysts, civil society activists, real estate as well as the creative and cultural industries, and government regulators seem to agree about its significance and positive value (DCLG,2009; Portas,2011; London Assembly,2013; Meanwhile Foundation,2016). Temporary use of space has been celebrated as a critique of the status quo and a catalyst for change (Eberle and Klanten,2001; Jovis,2007; Oswalt et al,2013; Temel and Haydn,2006), a progressive force, giving local communities and activists a stronger place as participants in urban transformation (Andres,2013; Langegger,2014; Fabian and Samson,2016). It is praised as offering new models of development and alternative experiences of places (Jodidio,2011; Németh and Langhorst,2014; Foster,2014).

It is therefore important that the subject be critically examined, its contexts and conditions of possibility scrutinized, and its idea and practices analysed. The subject has already attracted critical questioning as part of a critique of austerity urbanism (Tonkiss,2013; Ferreri,2015; E.Harris,2015). This paper's focus, however, is on the relationship between temporary use of space and the dynamics of spatial production, which locate the subject in wider urban processes and structural dynamics of political, economic and cultural change. The aim is to show how the temporary use of space is embedded in the material processes of urban development, as these processes have been adjusted to neoliberal globalization, economic restructuring, and recurring crises. With the help of a case study, temporary use is analysed as an integral part of the urban development processes, demonstrating its multivalent character, in which flexibility, opportunity and precarity are intertwined.

The research has been based on two theoretical and methodological frameworks: contextual and perspectival. The contextual strategy is based on the idea that the best way to understand a spatial phenomenon would be through retracing its process of production (Lefebvre,1991). In other words, the space does not have an intrinsic meaning: its multiple meanings are determined by the activities and subjectivities of the diverse groups of people who make it, through the phases of planning, development, management, representation, exchange and use. As a response to the crisis of vacant space, temporary use is a flexible method of spatial production, which cannot be separated from the processes 
of production and consumption of space, with their political economic and cultural dimensions (Lefebvre,1991; Harvey,2010).

At the same time, this process cannot be reduced to the conditions in which it takes place (Badiou,2005; Zizek,2014), as it can develop in a number of different ways. Through perspectival analysis, therefore, these processes and their outcomes are shown to generate differential and deeply unequal outcomes for the participating parties, revealing the limits to the creative possibilities of the temporary use and the extent of inequality and vulnerability which some parties endure. While its primary purpose is filling the empty spaces by some activity, its outcomes range from access to catalysis and precariousness.

This study focuses on the privately-owned space, as distinctive from the temporary use of the public space, which is a related but different process. By 'temporary use of space', what is implied is the shortterm, alternative use of a privately-owned and managed vacant space. The combination of 'alternative' and 'short-term' create the conditions of flexibility that are sought to make the space available and usable. The case study of Chesterfield House is selected, as it facilitates a contextual and perspectival analysis. It clearly demonstrates the different phases of urban development, making it possible to chart the states of the site before, during and after the temporary use. It has also made it possible to show the perspectives of the different stakeholders, their intentions, claims and roles. Its data are gathered from the publicly accessible records of the planning process, announcements of the different stakeholders, and reports in the local and national media.

The paper is organized in four parts. The first three parts investigate how empty spaces are produced, examine temporary use as a flexible method of spatial production, and analyse the temporary use as a multivalent opportunity that goes beyond its conditions of possibility, finding a cultural meaning that is used to lubricate urban development and mediate urban social change. The fourth section brings these investigations together in a case study, to show the range of different actors involved and their unequal roles, expectations and benefits.

\section{Production of empty space: temporal and spatial fluctuations of capitalism}

Empty urban spaces are an integral part of the urban development processes and the products of the temporal and spatial fluctuations that are inherent in capitalism: the temporal cycles of boom and bust, and the spatial patterns of investment and disinvestment. When combined and magnified, as in the crises of globalization and structural technological and economic change, these spatial and temporal fluctuations may leave large amounts of empty space behind.

The cyclical nature of capitalism generates temporal fluctuations in the production of space. The production, supply, demand, distribution, management and consumption of space are an integral part of capitalism and subject to its variations and recurring crises (Harvey,2010;1985). The forces of production speculatively act as a blind force in their search for perpetual expansion and higher rewards (Lefebvre,1991; Aglietta,2000). They tend to concentrate on activities and places that appear to facilitate their own growth, without the ability or interest in calculating the unintended consequences of such concentrations, hence regularly going through periods of crisis. The episodes of economic expansion frenetically produce space, while the periods of contraction are faced with an oversupply of space, a mismatch between supply and demand. Empty spaces, therefore, are an inherent feature of capitalism with its cyclical nature and its recurring crises.

With neoliberal globalization, constraints on capital's mobility have been loosened, accelerating global interdependencies while amplifying capitalism's inherent temporal crises to unprecedented levels. After Latin America and Asia, the global tides finally arrived in the West in 2007, leaving large wastelands in their wake and wiping out years of economic and social progress (European Commission,2010b:5). The debt-fuelled spatial production was part of a consumption-based economy relying on an oversupply of credit, which was no longer sustainable, as shown by the triggering role of the so-called sub-prime 
mortgages in the global financial crisis of 2007-8 (Harvey,2010; Cadman et al,2016). The crisis revealed the difficulties of constructing a global economic architecture on the basis of deregulation and marketization. The model of consumerist, laissez-faire development which accompanied globalization was now questioned even by its supporters (Barber,2009).

Empty spaces are also the outcome of spatial fluctuations in urban development, which are amplified in the global reorganization of production. Individual decisions, market operations or public policies generate patterns of investment and disinvestment within and across localities. These include suburbanization, whereby houses, shops and offices migrate to car-dependant, larger spaces in the suburbs, hollowing out city centres in much of the world. They also include the effects of planned changes, generating a waiting game, a planning blight, whereby the prospect of change prevents new investment in an area, losing economic value and activity. Emptiness may also follow the loss or realignment of functions, in small or large scales, as exemplified by the creation of new central business districts in some Asian cities, which leave the old centre underused and partially empty.

Globalization has intensified spatial fluctuations in urban development, generating a new global division of labour, redrawing the map of industrial production, relocating activities from older industrial regions to emerging ones, and thereby transforming the spatial arrangements in both deindustrializing and industrializing regions. This economic restructuring has led to economic decline and spatial dereliction, leaving large tracts of empty and abandoned space for over a generation (Kivell and Lockhart,1996; Couch and Cocks,2011), where both labour and space have been considered as obsolete and ready for 'creative destruction' (Schumpeter,2003; Perez,1983). The change 'from metal-bashing to knowledge generation' (Stiglitz,1999:15), from the accumulation of physical capital to the economic application of knowledge (UNESCO,2005:46), from manufacturing to services, from production to consumption, from organized mass production to flexible and dispersed production has left many empty holes, marked by deep inequality (OECD,2008;2011; National Equality Panel,2010; European Commission,2010a). With globalization, economic restructuring, and the global crisis, these temporal and spatial fluxes of capitalism have led to a dramatic rise in the number of empty office, residential and retail units.

By the turn of the century, the construction industry's share of the GDP in the UK, US, France and Germany had reached around 5\% (Blake et al,2004). The credit crunch crippled the construction sector, alongside many other sectors; in the UK, the construction sector contracted by $17 \%$ (Cadman et al,2016). As companies went bankrupt or downsized, the demand for office space shrank and the gap between supply and demand widened. Between 2007 and 2008, office vacancy at the heart of London's financial district grew by $50 \%$ (Ruddick,2008). By 2009, it reached more than $3 \mathrm{~m}$ square metres or around $12 \%$ of the City's office space (Ruddick,2009). The oversupply of office space was not limited to central London, however. As the chief executive of the property lobby group British Property Foundation observed, 'any trip through our suburbs soon exposes redundant office space that with the best will in the world is never going to be brought back into commercial use' (Donnelly,2015).

The impact on speculative residential developments was devastating. In Ireland, a country of 4.5 million population, more than half a million dwellings were built during 1995-2005. By 2012, about 300,000 homes were empty, amounting to $15 \%$ of the country's homes, with 1850 'ghost' housing estates unfinished (Flynn,2012). In Spain, an estimated 1 million new homes were left empty after the financial crisis and the collapse of the property market (Day,2012). Dubai, which seemed to be at one point a huge building site, was left with thousands of empty apartments (Spencer,2010). In China, dozens of ghost towns built on a speculative basis were left vacant (Banerjee and Jackson,2012), including the 'world's biggest mall' (Nylander,2013).

Empty shops changed the character of towns. There were more than 290,000 retail outlets in the UK in 2015 (Retail Economics,2016), accounting for more than 10\% of the UK employment; with sales of 
$£ 300$ bn in 2011 equivalent to $20 \%$ of the country's GDP (British Retail Consortium,2012). After the crisis, vacant shops rapidly increased as retail businesses failed (British Retail Consortium,2013), from only $3.3 \%$ in 2008 to $14.1 \%$ in the spring of 2013 (Local Data Company,2013), an estimated number of 30,000 empty shops in the UK (VPS,2013). By the summer of 2012, the rate of shop vacancy had reached a peak of $14.6 \%$, from around $10.7 \%$ in London to $20.1 \%$ in the Northwest of England, $30.6 \%$ in a large city like Nottingham, and up to $32.4 \%$ in a medium-sized city like Dudley (BBC,2012a; 2012b; 2012c). Although disputed by local authorities and town centre managers, these figures indicated considerable decline in British high streets. While the rates of shop vacancy have since improved, reaching an average of $12.5 \%$ in March 2016, high streets continue to be punctured by empty shops (Gallagher,2016). The drop in shop vacancy, however, was not interpreted as a sign of health for retailing, as many shops were converted to other uses, demolished or redeveloped (Felsted,2015).

In addition to the credit crunch, competition from online shopping and suburban supermarkets has undermined the viability of smaller retailers, indicating a growing gap between the declining town centres and the improving out-of-town shopping centres and retail parks (Gallagher,2016). Even giant supermarkets, however, have faced a degree of market saturation and decline (Wood and McCarthy,2014). The growing popularity of online shopping has been such that the independent regulator for communication industries called the UK 'a nation of online shoppers' (Ofcom,2013). The viability of retail units, therefore, is facing an existential threat, going beyond the problem of cyclical overproduction but caused by technological and organizational changes in the structure of the economy. It is predicted that by the end of the decade, online shopping will account for more than $21.5 \%$ of retail transactions, the total number of shops will be down by $22 \%$, and up to 28,000 town-centre shops will be lost (Centre for Retail Research,2013). It shows the changes in technology and social habits, as well as the limits of the model of retail-led, consumerist urban regeneration.

The large numbers of empty dwellings, offices and shops, therefore, are the outcomes of broader urban development processes embedded in the global market economy. Empty spaces are produced by the temporal and spatial fluctuations of the increasingly uncontrolled operations of a blind force at a global scale, its cycles of boom and bust and its patterns of investment and disinvestment, with its inherent, multi-layered and overlapping crises. The cyclical crisis of overproduction magnified to global levels, the changes in the global division of labour restructuring the local economies and relocating activities, the technological changes accelerating transformation and interdependencies, and the failure of the global economic architecture and of the local consumerist model of regeneration have all contributed to the production of empty spaces. The temporary use of space is thought to be a temporary response.

\section{Temporary use and flexible production of space}

Empty spaces indicate a crisis in spatial production, when supply far exceeds demand. When growing in size and scale, empty spaces would even signify a state of political crisis and economic decline. The presence of large amounts of vacant space points to economic failure, social desertion and deeper urban problems that are spatially expressed (Jacobs,1970). Faced with the large-scale and long-term vacancy of space, therefore, market mechanisms and state regulations have been used to induce a degree of flexibility in spatial production, which has tended to take four forms: price adjustment, supply reduction, functional conversion, and temporary use of space.

Price mechanism is the usual mode of flexibility in market exchange relations. According to neoclassical economists, the equilibrium of supply and demand ensures the provision of appropriate amounts of goods and services to the market (O'Sullivan,2012). This balance may be unsettled in periods of uncertainty or excess, but it may be restored by making adjustments to the supply or demand. The price mechanism, furthermore, is thought by free market analysts to be an efficient medium of information about the demand (Hayek,1945). After the crisis, in Ireland, residential property prices in 2012 were 64\% lower than 2007 (Flynn,2012). In Spain, property prices dropped by 22\% between 2007 and 2012, and banks offered housing units at $50 \%$ of their original prices to get them off their lists (Govan,2012). 
In some cases, property prices fell to a third of their original level (Brignall,2012). The magnitude of the problem was such, however, that the price mechanism could not be enough.

A more radical solution, which required government intervention, was the reduction of supply through demolition, as acknowledged by the Irish government (Kelly,2011). In the UK in 2015, more than 600,000 homes were empty, a third of which considered long-term, i.e., more than 6 months (Parkinson,2015). The response in some shrinking cities was demolition and redevelopment, as controversially exemplified by Glasgow and Liverpool (Hopkirk,2013).

Flexibility in spatial production was also facilitated through land-use conversion, particularly from the oversupplied office to highly-priced residential space. In 2013, the UK government introduced a temporary planning measure to facilitate this conversion through permitted development rights, removing the need for planning permission. Between April 2014 and June 2015, 4000 conversions were approved; by 2015, this measure was made permanent, justified as a solution to the housing crisis (DCLG,2015). In London, in particular, population growth, underinvestment in local housing needs, a globalized market, abundant liquidity and increased inequality led to a severe shortage of affordable housing. It was argued that, 'The move will provide thousands of new homes, and make the best use of existing buildings including some that are underused and neglected' (DCLG,2015). Property developers welcomed this move, aware that their office overproduction could not wait for the turn of the economic cycle (Donnelly,2015). The policy excluded a number of areas, including parts of central London and Manchester, where office spaces were protected from automatic conversion. High housing prices attracted many developers to convert these spaces, to the extent that there were concerns about the policy's impact on the future availability of office space, even though the value of commercial property had recovered in these hotspots and a new crash was being expected (Barrett,2015).

Temporary use of space was the fourth form of flexibility, which showed the limitations of price adjustment, supply reduction, and functional conversion. It was especially used in retail, which suffered from a phenomenal number of empty units and an existential concern for the future of the high street $(N E F, 2010)$. Temporary use of empty space became an instrument of filling the gap, an interim measure until the upturn of the economic cycle. According to a UK government report, 'It is vital that we do all we can to enable vacant properties to be used for temporary purposes until demand for retail premises starts to improve.' (DCLG,2009:27). The pop-up and interim use of empty high street units was seen as good practice in the fight against decline (London Assembly,2013).

A government-commissioned report argued for helping landlords to let their property on a temporary basis: 'Better to have something in them than stand empty' (Portas,2011:40). The government introduced 'meanwhile use' leases and guidance for landlords, 'to encourage the temporary occupation of empty town centre retail premises by non-commercial occupiers, who will be able to contribute to town centre vitality but who would otherwise be unable to afford normal commercial rents' (DCLG,2013). The non-commercial users would include voluntary or charitable groups, information centres, artists and musicians, among others. Standard legal instruments were provided that could be freely used by potential applicants, intended to reduce the administrative and legal costs for landlords and tenants.

A movement of searching for temporary uses for empty shops was launched. Analysts monitored the number and changes of empty shops in towns and cities (Local Data Company,2013). The Empty Shops Network (2016) was set up by Revolutionary Arts in 2008 and continued to offer advice and facilitate access to redundant spaces in towns and cities. It provided advice on how to plan and launch a successful pop-up business, find the appropriate space and sympathetic landlord, and promote and manage the pop-up (Thompson,2012). Another initiative, Pop-up Britain was launched 'to give new British brands a rare opportunity to get their products onto the British high street' (VPS,2013). Another network, London Pop-ups, provided details of the pop-up restaurants, bars, shops, galleries, and gigs 
in London. Advice on interim retailing became available in many parts of the UK (Invest Northern Ireland,2016).

The temporary use shows a pragmatic attitude towards empty spaces, as the loss of employment, investment and function leaves big holes that need filling. It becomes an instrument of dealing with the crisis of overproduction, addressing the mismatch between demand and supply through encouraging flexibility in supply, in the hope of an increase in demand. It offers access at lower costs, ensures that landlords can see some return on their investment, and helps public authorities to maintain a degree of vibrancy and avoid the dark appearance of decline. However, compared to the size of the problem, and the number of empty shops, the contribution of temporary use has been very modest, as judged by the number of projects that the 'market leader' in temporary use has undertaken (Meanwhile Space,2016).

Temporary use, therefore, represents a flexible method of spatial production, whereby some established approaches to spatial control and use are briefly suspended. It shows the limitations of the other methods of flexibility in the wake of a major global crisis, especially the price mechanism and the supply-demand equilibrium. The crisis went far beyond the periodic economic cycles, as the global reach of capitalism exposed localities to frequent global crises of much higher magnitudes. In deep economic crisis and a combination of overproduction, inequality and maldistribution, the demand for, and the exchange value of, fixed goods such as space had severely contracted, which demanded flexibility not only in price and function, but also in time.

\section{The space of opportunity and precarity}

Temporary use of space is an example of what the ancient Greeks called Kairos, an opportunity that captures 'all the possibilities contained within a given moment', which entails knowing how to seize and utilize this opportunity (Hadot,1995:221). It signifies flexibility in supply, presented as an opportunity for producers and users alike, with interweaving economic and cultural meanings. For producers, it is an opportunity to fill some gaps, utilizing and increasing their assets. For most temporary users, meanwhile, access to space at a low cost, which would not be affordable otherwise, constitutes this opportune moment, facilitating experimentation and developing new capacities, acting as a stepping stone towards a new career or constructing a new enterprise (Bishop and Williams,2012; Berwyn,2013; Steele,2013; Andres,2013; Langegger,2014; Fabian and Samson,2016; Foster,2014; Németh and Langhorst,2014; Eberle and Klanten,2001; Jovis,2007; Oswalt et al,2013; Temel and Haydn,2006).

In this process, the opportune moment finds a cultural value, displaying, at least for some, a transition from the realm of necessity into the realm of choice, and the assertion of status. The opportunity to grab something while it briefly lasts finds a celebratory character, becoming a desirable choice rather than a sign of vulnerability and instability, turning into a trait that signifies a new cultural status. This is especially the case for those who are not suffering from a lack of opportunities, for whom the temporary use of space is not a necessity, but an opportunity of a different kind. For them, the image and attention in a competitive market may be the rationale for temporary use. The idea of temporary use of space is, therefore, turned into a desirable social trend.

The examples include temporary shops and restaurants by major companies, which are driven not by necessity but by choosing a fashionable idea that may increase visibility, a marketing tool in the attention economy. As the London Pop-ups website advises its readers: 'A pop-up shop is a great hook to use to get press for your brand, so make sure you get the word out that you are offering something new and different for a limited time only' (Calladine,2012). Between July and December 2012, as reported by Vogue, Chanel opened its first standalone shop in London's Covent Garden as a pop-up shop (Alexander,2012). Claridge's, an exclusive London hotel, set up a pop-up restaurant during the Olympics (Norman,2012). The 200-year old shoemakers Clark opened a pop-up shop in London, followed by another in Toronto, which was hailed as a marketing success, creating a new 'consumer experience' by bringing the brand to life in a new way (R.Harris,2015). In Milan Design Week, in a period 
of exhibitions which by definition is a temporary event, the term temporary is used to name some spaces and events, as the indication of a specific trend. This included the Swedish furniture giant IKEA, which established a shop called IKEA-Temporary, near Zona Tortone, an area in which disused industrial spaces have been used for the display of creative work by local and international designers (IKEA,2016).

From a tool of crisis management, temporary use of space is therefore turned into a branding exercise, generating the impression of experimentation and freshness. When it finds this symbolic value as a vehicle of branding, it is adopted by corporate organizations to show being aligned with an emerging trend. As it tends to be associated with young entrepreneurs in creative and cultural industries, the image of the trend is not tarnished by the traditional imagery of deprivation and poverty, but it rides on the image of creative energy and the prospect of future wealth creation. This conversion of necessity to choice, of the change in the status of an action, of normalization of opportunism, may disconnect the title from the content and reformulate it in a new way. It is done by those who, in Bourdieu's terms, have symbolic power, i.e., 'the power to make things with words' (Bourdieu,1989:23).

In the shift from necessity to choice, a displacement of cultural meaning takes place. This displacement runs in parallel, and at times is associated with, social and economic forms of displacement and their spatial expression. Gentrification has long benefited from the change of imagery that artists and creative industries bring to a declining area (Atkinson and Bridge,2005; Lees et al,2008). Their arrival in an area that may be endowed with spatial capacities but suffering from economic decline is powerful enough to change its image, paving the way for the real estate industry and higher income residents to move in. In time, artists are priced out and the cycle of gentrification is complete. One displacement leads to another: while artists displace the image of decline, they are displaced by the image of prosperity, a process in which opportunity and precarity are entwined.

The parallels with temporariness and precarity in housing and employment are clear. In housing, temporary use is expressed in the rise of short-term renting, as the more long-term access to residential space becomes unaffordable for many young people. The most common form of residential renting is an Assured Shorthold Tenancy, which was introduced in 1988, reducing the levels of protection that a private tenant enjoyed (UK Government,2016). Renting has always been a form of temporary use of space, but the length of the period and the conditions of use were now made far less secure. By 2025, it is anticipated that more than half of people under the age of 40 would be renting from private sector landlords, unable to afford owning their homes. A 'generation rent' has been identified, unable to enjoy the levels of stability and security that previous generations enjoyed (Osborne,2015). When applied to homes and workplaces, the intensified use of temporary space is an expression of precarity and insecurity. It runs parallel with insecure forms of employment and the epidemic rise in the sense of anxiety among the young (Hutton,2016).

Temporary use, therefore, is a flexible form of spatial production that offers an opportunity: to producers for maximizing the use of their assets, to public authorities for avoiding the image of decline, to creative entrepreneurs for accessing low-cost space, to corporate organizations for branding through a cultural trend, and to real estate industry for gentrification. Under the banner of a shiny cultural trend, a philanthropic front offers support and simultaneously normalizes precarity and displacement for those who have to move on as the brief opportunity comes to an end. As such, it is part of the broader urban processes with multivalent economic and cultural implications for different stakeholders. Reliance on such opportunities transforms the concept of time and temporality, from a consistent infrastructure and a predictable prospect, which had become a cornerstone of the welfare state, to a kaleidoscope of precarious and uncertain moments within continuously recurring storms and crises, which have signified the neoliberal globalization. Searching for opportunity within the conditions of uncertainty, therefore, could characterize the temporary use of space. 


\section{Chesterfield House}

The case of Chesterfield House in London brings together these three dimensions of crisis, flexibility and opportunity and locates them in broader urban development processes. It demonstrates the patterns of the production of emptiness, introduction of flexibility in spatial production, and application of temporary use, with its opportunities and limitations, and their roles in property development.

Chesterfield House was a 7-storey, 1960s office building in central Wembley, London, used by Brent Council's education department before its move into the new civic centre in 2013 (King,2015). This was part of a move that sold the old Town Hall, bringing all of Borough Council's activities to a single location to save $£ 2.5 \mathrm{~m}$ in annual costs (Wainwright,2013). The new building, where the council chamber is available to rent for conferences, is described as 'a machine to make money' and 'a fitting monument to our corporate times' (Wainwright,2013). The relocation left Chesterfield House empty, which could not be used in its current form. In 2008, the council had renewed a 2001 planning permission for replacing it with two new office buildings (Brent Council,2016). As reported in the Webley Masterplan, however, the council had already given consent for a considerable amount of office floor space in the area, which were not yet built or even under active consideration. The credit crunch had caused a major crisis of emptiness in central London and there was no hope that Webley could compete in attracting office users; the lack of markets for suburban office space was indeed well documented by the Greater London Authority (Brent Council,2009:52). Two further applications in 2009 and 2012 for building student accommodation and a hotel were withdrawn (Brent Council,2016).

The empty space was the result of functional relocation, technological obsolescence, and the overproduction of office space caught in a global crisis. In response, all forms of flexibility in spatial production were employed to deal with the empty space: no information is available on the price, but it was probably adjusted to reflect the market conditions. The supply was reduced by the demolition of the empty office building, the land use was converted from office to housing, and the temporary use of space was employed to fill the temporal gaps and prepare for the change. The development process shows an empty office building that was first used by temporary users and then demolished and rebuilt as high density housing. The process was led by a local charity, in collaboration between the local authority, an investor, a developer, a social enterprise that occupied the space and another that marketed its spaces.

The temporary use project was led by Meanwhile Foundation (2016), a charitable organization set up in 2012 by Brent Council and Locality, the national network of community-led organizations. The Foundation's aims were stated as helping to 'create social and economic value from vacant property' and working with 'developers, landowners, local authorities, charitable organisations and specific local projects to convert vacant property into opportunities for workspace, training and community projects' (Meanwhile Foundation,2016). By using its charitable status, which would ensure relief from business rate, the Foundation would become the tenants of vacant properties and would help people, who would otherwise not be able to afford the space, to make use of it in a way that supports their neighbourhoods. In doing so, the charity could help landlords and developers with the lost revenue and contribute a degree of vitality to local neighbourhoods.

The project was part of the Coming Soon Club, a local group of young people whose aim was to help the people in Wembley to start temporary projects. The Club managed the marketing of spaces, introducing Chesterfield House as 'an enterprise hub', 'a temporary enterprise space', with wifi, support staff and low costs, where a desk, a studio or event space were available at rents between $£ 60$ and $£ 300$ a month 'to try anything' (Coming Soon Club,2016). Another intermediary, Create Space London, announced its partnership with Meanwhile Space to provide 'Studios, workshops \& space, for artists, designers, makers and hackers' in Chesterfield House, at a rent of from $£ 185$ to $£ 750$ a month (Create Space London,2015). While the local media announced that the developers had made the building available rent free (King,2015), the actual rent for temporary users was advertised for up to $£ 750$ for a 
50 square-foot studio. Six storeys of the empty office block hosted 52 temporary users for 10 months until January 2016, allowing them 'to try out their projects, events, and use flexible workspace' (Meanwhile Foundation,2016).

The temporary use of the space was arranged by Meanwhile Space, a social enterprise established in 2009 when, jointly with Development Trusts Association (now Locality), it set up the Meanwhile project for the Department for Communities and Local Government (Meanwhile Space,2016). By trademarking the title Meanwhile, it boasts to be 'the market leader in Meanwhile uses', specializing in the 'intelligent use of unproductive empty buildings and underused land', with clients in local and central governments, real estate, construction and creative industries. Its declared ethos is that 'empty space is wrong and can be used to create opportunities for people'. It aimed at maximizing the use of space for the entire period that a property is left empty, as distinctive from pop-up spaces, which were used for just a few weeks. By 2015, it reported to have bought 100,000 square feet, occupying 44 properties, supporting 511 people into its spaces and creating 170 jobs in predominantly deprived town centre neighbourhoods, while saving £685,000 in empty property rates for their landlords (Meanwhile Space,2016).

The project was a partnership with Brent Borough Council, in collaboration with the Hub Group, a midmarket housing development company in London. The developers had acquired the building in 2014 and by 2016 they were given planning permission to turn it into 239 apartments with associated retail space, a new public square, community facilities and parking (Hub Group,2016). The developers were in partnership with Bridges Ventures, a social impact investment fund which claims to be the only one of its kind, providing 'investment and support to charities and social enterprises' (Bridges Ventures,2016). Brent Council granted the planning permission, which included raising $£ 5.5 \mathrm{~m}$ Community Infrastructure Levy, in a project that increased the site's floor space from around 7,000 to 26,000 square metres (Brent Council,2016:39). In doing so, the Council dismissed the objections that the height of the two buildings was out-of-context with negative impacts on the infrastructure and views in the area, that Brent residents will not be able to afford the flats, and that two towers separated the renters from the owners (Brent Council,2016).

The story of the project, therefore, shows that a development company and an investment fund buy an empty office building and convert it into housing towers. This conversion of land use and building form is mediated by a period of 10-months temporary use while the planning process was ongoing, which came to an end in January 2016, before the planning permission was granted by Brent Council in April 2016. This conversion and mediation was facilitated by the financial reliefs that the charitable status of some stakeholders could bring about, reducing the risks to the private investors. The project also shows the densification of the site by adding the twin towers that are the tallest buildings in Wembley. The size and volume of the new project are not in keeping with the area's character, but in a city with severe housing shortage, a city now used to high rise buildings cropping up everywhere without much attention to the surrounding context, this conversion is acceptable by the local planning authority. During the period of transition, while processing the planning application, which links this conversion to the provision of some affordable housing and community facilities, the empty property is still generating some income by savings on rates and temporary use.

The 'creation of meanwhile space for local start-up businesses and creative enterprise' was included in the Community Involvement Statement of the planning application (Brent Council,2016: 20). It was hoped that allowing the building to be used by some community and creative groups would change the image of the developer and the development project in the eyes of the local residents. As a director of the development company stated,

'Enabling vibrant, community oriented, uses in the building is our way of engaging and understanding the existing community before coming forward with our redevelopment plans. 
Creating meaningful relationships in Wembley Central is important for us as we bring forward proposals for a new residential led scheme.' (Quoted in King,2015).

Looking from the perspective of this planning and development process, therefore, it becomes clear that temporary use is not in the driving seat, but a side event alongside the main residential development project, acting as a sweetener for the local community and a vehicle of legitimizing the major changes that take place on the site. The temporary users' involvement is just a brief moment in the two almost permanent histories of the site before and after their presence. The temporary use of space was a stopgap, in a process in which the primary beneficiaries seem to have been the investors and developers who could expand their space in a vibrant housing market and, to a lesser extent, the local community who could receive some new facilities.

From a pragmatic perspective, temporary use was a productive use of empty space and provision of access to space for those who could not otherwise afford it. But it also shows how far the precarity of employment for the young and the inequality of access to space are taken for granted. The conditions of inequality, which are recognized by most analysts (OECD,2008;2011; National Equality Panel,2010; European Commission,2010a), are taken as natural. The process shows a support package for the landlords and developers, some benefits for the locals, and temporary access to space for insecure, creative entrepreneurs. It addresses the losses caused by the oversupply of office space, which shows no hope of reuse, rather than providing new affordable space for the activities that need it. It draws on a government-backed flexibility in regulatory frameworks, and on a landlord- and developer-backed flexibility in interim use. As such, it shows a temporarily flexible approach to the production of space, limiting its scope to removing the existing surplus, where it exists, from the marketplace, and converting it into a profitable land use. The short-term beneficiaries are expected to be grateful for this opportunity, knowing that they are temporary users and should not invest high hopes in the continuity of this opportunity. The long-term beneficiaries, however, have been able to reduce their risks, maximize their gains from the higher density development, and construct in the age-old way of speculative development for a rather secure market.

In some places, temporary use is associated with gradual adjustments by individual actors over time, as in the emergence of artists' clusters in cities. Their concentration helps change an area's image into a fashionable hub of cultural activities, which is then translated into real estate value by investors and gentrifiers. What we are now witnessing in Chesterfield House is a formal endorsement and temporal acceleration of temporary use, which is utilized to hasten this change, squeezing the entire cycle of transformation and displacement into a much shorter timeframe, creating the Kairos rather than waiting for it to happen. The temporary users, who may be happy to have been given the chance, in fact contribute heavily to the monetary value of the space through their own cultural capital, without being able to benefit from it themselves. The 10-month presence of creative users provided this accelerated period of image-transformation, paving the way for a complete change of the scene in a much faster pace, rather than waiting for the gradual changes to do the work over a much longer time. Temporary use of space helped lubricate the property development process, accelerate the change of image and function, and manage some of its side effects through resorting to a fashionable cultural trend.

\section{Conclusion}

This paper has argued that the temporary use of space should be analysed in the context of the urban development process as a whole. From this perspective, temporary use is shown to be a moment in a complex process, offering some opportunities, but also revealing the precariousness and vulnerability of its users. Temporary use, therefore, lies at the intersection of contextual crises, flexible responses, and multivalent consequences.

Vacant spaces are produced by spatial and temporal fluctuations: the relocation of activities, the cyclical nature of capitalism, and its recurring crises of overproduction, made more frequent and magnified by 
globalization. Changes in technology and the global division of labour have exposed local development processes to the wild moods of a blind force, creating long-term vulnerability and emptiness. In response, government regulations and market mechanisms have been mobilized to induce a degree of flexibility in spatial production, which includes the temporary use of space, alongside the more traditional methods of price adjustment, functional conversion and supply reduction.

Temporary use is a pragmatic measure, a multi-faceted process claimed to be beneficial for all the parties involved: access to space for creative entrepreneurs and local communities, loss prevention for landowners and developers, and revitalization of towns and cities for local and central authorities. When the temporary use of space is analysed in the context of a larger process of spatial production, and from different perspectives, however, it becomes clear that temporariness finds different meanings and implications for different parties. For some, it is a brief moment of opportunity in a general situation of insecurity and vulnerability, while for others it accelerates the change of image, mediates the market conditions, and legitimates substantive gains.

The temporary use of private space should be understood as the introduction of a degree of flexibility to the conditions that frame the production of space, especially when facing a major crisis, which tends to be concentrated in the most affected areas. The image of this flexibility, however, finds a cultural value that goes beyond its conditions of possibility, normalizing an attitude that takes inequality for granted, and hiding the unbalanced outcomes for different stakeholders. It introduces a flexible method of spatial production, which would correspond to the conditions of flux in which such production takes place. As it lubricates structural change and its associated risks, this flexibility corresponds to a range of conditions, ranging between necessity and choice, which depends on the position of those involved in the process. While this flexibility may present an opportunity, particularly for the investors who may be helped to reduce their risks, it also reveals the precarity of conditions for those who have limited access to resources, who may pave the way for economic transformation and social displacement. By definition, this flexibility is a temporary one, and with the end of a phase, the framing conditions of space may completely change.

\section{References}

Aglietta,M., 2000, A Theory of Capitalist Regulation, London: Verso.

Alexander,E., 2012, Chanel comes to town, Vogue, 12.7.2012, http://www.vogue.co.uk/news/2012/07/12/chanel-opens-covent-garden-beauty-pop-up-store, 17.11.2012.

Andres,L., 2013, Differential Spaces, Power Hierarchy and Collaborative Planning: A Critique of the Role of Temporary Uses in Shaping and Making Places, Urban Studies, 50(4), pp.759-775.

Atkinson,R. \& G.Bridge, 2005, eds, Gentrification in a Global Context, London: Routledge.

Badiou,A., 2005, Being and Event, London: Continuum.

Banerjee,R. \& P.Jackson, 2012, China's ghost towns and phantom malls, BBC, http://www.bbc.co.uk/news/magazine-19049254, 24.05.2013.

Barber,L., 2009, Capitalism redrawn, Financial Times: The Future of Capitalism, 12 May 2009, p.3.

Barrett,C., 2015, Commercial property crash fears loom large, Financial Times, 13 November 2015, https://next.ft.com/content/ef36c6be-89f2-11e5-9f8c-a8d619fa707c, 12.5.2016. 
BBC, 2012a, Empty shop rate rises across Britain as spending drops, BBC News, 4 September 2012, http://uww.bbc.co.uk/news/business-19465725, 17.11.2012.

BBC,2012b, Nottingham centre has 'most vacant shop space', BBC News, 4 September 2012, http://www.bbc.co.uk/news/uk-england-nottinghamshire-19470553, 17.11.2012.

BBC,2012c, Dudley 'worst among medium centres' for empty shops, BBC News, 4 September 2012, http:/www.bbc.co.uk/news/uk-england-birmingham-19470562, 17.11.2012.

Berwyn,E., 2013, Mind the gap: Creating opportunities from empty space, Journal of Urban Regeneration and Renewal, 6(2), pp.148-153.

Bishop,P. \& L.Williams, 2012, The Temporary City, London: Routledge.

Blake,N., J.Croot \& J.Hastings, 2004, Measuring the Competitiveness of the UK Construction Industry, Volume 2, London: Department for Trade and Industry.

Bourdieu,P., 1989, Social space and symbolic power, Sociological Theory, Vol. 7, No. 1. (Spring, 1989), pp. 14-25.

Brent Council, 2009, Wembley Masterplan, London: Brent Council.

Brent Council, 2015, Wembley Area Action Plan, London: Brent Council, http://brentconsult.objective.co.uk/portal/planning/waap_1?pointld=1377272340551, 11.1.2017.

Brent Council, 2016, Committee Report, http://democracy.brent.gov.uk/documents/s39059/ , 12.06.2016

Bridges Ventures, 2016, Bridges Social Impact Bond Fund, http://bridgesventures.com/social-sectorfunds/social-impact-bond-fund/, 7.06.2016.

Brignall,M., 2012, Spanish property: Polaris golf resort homes crash to a third of original price, The Guardian, 25 May 2012, http://www.guardian.co.uk/world/2012/may/25/spanish-property-polarishomes-crash, 18.11.2012.

British Retail Consortium, 2012, UK Retail: Leading globally, serving locally, London: British Retail Consortium.

Cadman,E., S.Bernard, T.Pearson, 2016, The UK Economy at a Glance, Financial Times, https://ig.ft.com/sites/numbers/economies/uk, 5.05.2016.

Calladine,D., 2012, Advice and Resources, London Pop-ups, http://www.londonpopups.com/p/adviceresources.html,17.11.2012.

Centre for Retail Research, 2013, Retail in 2018, http://www.retailresearch.org/retail2018.php, 12.06.2016.

Cochrane,K., 2010, Why pop-ups pop up everywhere. The Guardian, http://www.theguardian.com/lifeandstyle/2010/oct/12/pop-up-temporary-shops-restaurants, 28.06.2016. 
Colomb,C., 2012, Pushing the urban frontier: Temporary uses of space, city marketing, and the creative city discourse in the 2000s Berlin, Journal of Urban Affairs, Vol.34, No.2, pp.131-152.

Coming Soon Club, 2016, Chesterfield House, http://www.comingsoonclub.co.uk/chesterfieldhouse/enterprise-hub/, 7.06.2016

Couch,C \& M.Cocks, 2011, Housing Vacancy and the Shrinking City: Trends and Policies in the UK and the City of Liverpool, Housing Studies, 28 (3): 499-519.

Create Space London, 2015, New Second Premises @ Wembley Central, http://createspacelondon.org/new-premises-wembley-central-2/, 12.06.2015.

Day,P., 2012, Crisis draws squatters to Spain's empty buildings, Reuters, 28 May 2012, http://uk.reuters.com/article/2012/05/28/uk-spain-squatters-idUKBRE84R09D20120528, 18.11.2012.

DCLG, 2009, Looking After Our Town Centres, London: Department for Communities and Local Government.

DCLG, 2013, Meanwhile use leases and guidance for landlords, 16 October 2013, https://www.gov.uk/government/collections/meanwhile-use-leases-and-guidance-for-landlords, 6.06.2016.

DCLG, 2015, Thousands more homes to be developed in planning shake up, Press release, 13 October 2015, https://www.gov.uk/government/news/thousands-more-homes-to-be-developed-in-planningshake-up, 12.5.2016.

Donnelly,M., 2015, Government makes office-to-resi changes permanent, Planning Resource, http://www. planningresource.co.uk/article/1367939/government-makes-office-to-resi-changespermanent, 12.5.2016.

Eberle,M., R.Klanten, H.Hellige, M.Mischler, 2001, Temporary Spaces, Berlin: Die Gestalten.

Empty Shops Network, 2016, Empty Shops Network, https://emptyshops.wordpress.com/ Accessed 6.5.2016.

European Commission, 2010a, Why Socio-economic Inequalities Increase? Facts and policy responses in Europe, Luxembourg: Publications Office of the European Union.

European Commission, 2010b, Europe 2020: A strategy for smart, sustainable and inclusive growth, Brussels: European Commission.

Fabian,L., \& K.Samson, 2016, Claiming participation - a comparative analysis of DIY urbanism in Denmark, Journal of Urbanism, 9(2), pp.166-184.

Felsted,A., 2015, UK's empty shop figures fall to five-year low, Financial Times, 8 October 2015, https://next.ft.com/content/ead3a9aa-6c4e-11e5-8171-ba1968cf791a, 12.06.2016.

Ferreri,M., 2015. The seductions of temporary urbanism, Ephemera: Theory \& politics in organization, 15(1), pp. 181-191. 
Flynn,F., 2012, Ireland Bulldozes Ghost Estate in Life After Real Estate Bubble, Bloomberg, 20 July 2012, http://www.bloomberg.com/news/2012-07-19/ireland-bulldozes-ghost-estate-in-life-after-realestate-bubble.html, 18.11.2012.

Foster,J., 2014, Hiding in plain view: Vacancy and prospect in Paris' Petite Ceinture, Cities, 40 (2014), pp.124-132.

Gallagher,P., 2016, Short-term outlet vacancy rates jump across UK, Retail Gazette, Thursday 14 April 2016, http://www.retailgazette.co.uk/blog/2016/04/short-term-outlet-vacancy-rates-jump-across-uk, 6.05.2016.

Govan,F., 2012, The ghost towns of Spain: Images that are desolate symbols of collapsed property market, The Telegraph, 16.02.2012, http://www.telegraph.co.uk/news/worldnews/europe/spain/9087498/The-ghost-towns-of-SpainImages-that-are-desolate-symbols-of-collapsed-property-market.html\#, 18.11.2012.

Hadot,P., 1995, Philosophy as a Way of Life, Oxford: Blackwell.

Harris,E., 2015, Navigating Pop-up Geographies: Urban Space-Times of Flexibility, Interstitiality and Immersion, Geography Compass, 9/11 (2015): 592-603.

Harris,R., 2015, Clark opens pop-up shop in Toronto, Marketing, http://www.marketingmag.ca/brands/clarks-opens-pop-up-shop-in-toronto-158535, 8.06.2016.

Harvey,D., 1985, The Urbanization of Capital, Oxford: Blackwell.

Harvey,D., 2010, The Enigma of Capital, London: Profile Books.

Hayek,F.A., 1945, The Use of Knowledge in Society, The American Economic Review, 35, 4, pp. 519530.

Hopkirk,E., 2013, Drama as Pickles puts brakes on Liverpool Terrace demolition, BDOnline, 24 July 2013, http://www.bdonline.co.uk/drama-as-pickles-puts-brakes-on-liverpool-terracedemolition/5058209.article, 28.06.2016.

Hub Group, 2016, Chesterfield House, http://www.hubgroup.co.uk/projects/chesterfield-house, 7.06.2016.

Hutton,W., 2016, Only fundamental social change can defeat the anxiety epidemic, The Guardian, 8 May 2016, http://www.theguardian.com/global/commentisfree/2016/may/07/mental-health-policyanxiety-natasha-devon-young-people, 12.06.2016.

IKEA, 2016, II nuovo spazio temporaneo in centro a Milano, http://www.ikea.com/ms/it_IT/ikeatemporary/index.html, 8.06.2016.

Invest Northern Ireland, 2016, Set up a pop-up shop, https://www.nibusinessinfo.co.uk/content/set-popshop, 28.06.2016.

Jacobs,J., 1970, The Economy of Cities, New York: Vintage Books.

Jodidio,P., 2011, Temporary Architecture Now!, Cologne: Taschen. 
Jovis, 2007, Urban Pioneers: Berlin Experience with Temporary Urbanism, Berlin: Jovis.

Kelly,A., 2011, Demolition the last resort for Ireland's 19,000 houses in ghost estates, Irish Central, 14 October 2011, http://www. irishcentral.com/news/Demolition-the-last-resort-for-Irelands-19000-housesin-ghost-estates-131854748.html\#axzz2CZlk0lzQ, 18.11.2012.

King,L., 2015, Plans revealed to convert Chesterfield House in Wembley into mixed-used development,

Brent \& Kilburn Times, $21 \quad$ July 2015,
http://www.kilburntimes.co.uk/news/heritage/plans_revealed_to_convert_chesterfield_house_in_wem bley_into_mixed_used_development_1_4162241, 12.06.2016.

Kivell,P. \& D.Lockhart, 1996, Derelict and vacant land in Scotland, Scottish Geographical Magazine, 112:3, 177-180.

Langegger,S., 2014, Reprint of "Emergent public space: Sustaining Chicano culture in North Denver", Cities, 40 (2014), pp.183-189

Lees,L, T.Slater \& E.Wyly, 2008, eds, Gentrification, London: Routledge.

Lefebvre,H., 1991, The Production of Space, Oxford: Blackwell.

Local Data Company, 2013, The Knowledge Centre, http://www.localdatacompany.com/knowledge, 23.5.2013.

London Assembly, 2013, Open for Business: Empty shops on London's high streets, March 2013, London: Greater London Authority.

Meanwhile Foundation, 2016, The Meanwhile Foundation is Open for Business, http://www.meanwhile.org.uk/, 6.06.2016.

Meanwhile Space, 2016, Coming Soon Club at Chesterfield House, http://www.meanwhilespace.com/projects/past/coming-soon-club-chesterfield-house/, 7.06.2016.

Moore-Cherry,N. \& L.Mccarthy, 2016, Debating Temporary Uses for Vacant Urban Sites: Insights for Practice from a Stakeholder Workshop, Planning Practice \& Research, 31(3), pp.347-357.

National Equity Panel, 2010, An Anatomy of Economic Inequality in the UK: Report of the National Equality Panel, London: Government Equalities Office.

NEF,2010, Re-imagining the high street: Escape from Clone Town Britain, London: New Economics Foundation.

Németh,J. \& J.Langhorst, 2014, Rethinking urban transformation: Temporary uses for vacant land, Cities, 40 (2014), pp.143-150.

Norman,M., 2012, A taste of Noma at Clardige's, London, The Telegraph, 7 August 2012, http://www.telegraph.co.uk/foodanddrink/restaurants/9458708/A-taste-of-Noma-at-Claridges-Londonrestaurant-review.html, 12.5.2016.

Nylander,J., 2013, World's biggest mall a China 'ghost town', CNN, http://edition.cnn.com/2013/03/03/business/china-worlds-largest-mall, 24.05.2013 
O'Sullivan,A., 2012, Urban Economics, Third Edition, Chicago: Irwin.

OECD, 2008, Growing Unequal? Income Distribution in OECD Countries, Paris: OECD.

OECD, 2011, Divided We Stand: Why Inequality Keeps Rising, Paris: OECD.

Ofcom, 2013, UK consumers are a nation of online shoppers, http://consumers.ofcom.org.uk/2011/12/uk-consumers-are-a-nation-of-online-shoppers/, 24.05.2013.

Osborne,H., 2015, Generation rent: the housing ladder starts to collapse for the under-40s, The Guardian, http://www.theguardian.com/money/2015/jul/22/pwc-report-generation-rent-to-grow-overnext-decade , 27.7.2015.

Oswalt,P., K.Overmeyer, P.Misselwitz, 2013, Urban Catalyst: The Power of Temporary Use, Berlin: Jovis.

Parkinson,J., 2015, Why are so many British homes empty? BBC Magazine, 2 December 2015, http://www.bbc.co.uk/news/magazine-34930602 , 12.06.2016.

Perez,C., 1983, Structural change and assimilation of new technologies in the economic and social systems, Futures, October 1983, pp.357-75.

Portas,M., 2011, The Portas Review: An independent review into the future of our high streets, London: Department for Business, Innovation and Skills.

Retail Economics, 2016, UK Retail Stats and Facts, http://www.retaileconomics.co.uk/library-retailstats-and-facts.asp, 12.06.2016.

Ruddick,G., 2008, Empty office space in City of London rises by almost 50pc, The Telegraph, http://www.telegraph.co.uk/finance/3117037/Empty-office-space-in-City-of-London-rises-by-almost-

50pc.html, 26.05.2013.

Schumpeter,J., Capitalism, Socialism and Democracy, 2003, London: Taylor and Francis.

Spencer,R., 2010, Dubai may have to knock down buildings constructed during boom, The Telegraph, http://www.telegraph.co.uk/news/worldnews/middleeast/dubai/8013438/Dubai-may-have-to-knockdown-buildings-constructed-during-boom.html, 24.05.2013

Steele,J., 2013, How 'Meanwhile' came to the High Street, Journal of Urban Regeneration and Renewal, 6 (2), pp.172-175.

Stiglitz,J., 1999, Public Policy for a Knowledge Economy, Washington DC: World Bank.

Temel,R., \& F.Haydn, eds, 2006, Temporary Urban Spaces: Concepts for the Use of City Spaces, Basel: Birkhauser.

Thompson,D., 2012, Popup Business for Dummies, Chichester: Wiley.

Tonkiss,F., 2013, Austerity urbanism and the makeshift city, City, 17(3), pp.312-324.

UK Government, 2016, Tenancy Types, https:/www.gov.uk/private-renting-tenancyagreements/tenancy-types, 13.06.2016. 
UNESCO, 2005, Towards Knowledge Societies, UNESCO World Report, Paris: United Nations Educational, Scientific and Cultural Organization (UNESCO).

VPS, 2013, Can innovation rejuvenate our high streets? 31 July 2013, http://www.vpsgroup.com/resource-centre/press-releases/uk-retail-schemes-to-revive/, 12.06.2016

Wainwright,O., 2013, Brent council's new £90m civic centre seen as machine for making money, The Guardian, Monday 3 June 2013, https://www.theguardian.com/artanddesign/2013/jun/03/brent-councilcivic-centre-opens, 21.12.2016.

Wood,S. \& D.McCarthy, 2014, The UK food retail 'race for space' and market saturation: a contemporary review, The International Review of Retail, Distribution and Consumer Research , Volume 24, Issue 2, pages 121-144.

Zizek,S., 2014, Event: Philosophy in Transit, London: Penguin. 